Andreas Losch and Andreas Krebs

\title{
Implications for the Discovery of Extraterrestrial Life - a Theological Approach
}

Keywords: Astrotheology, Extraterrestrials, Life, Universe

Abstract: The recent remarks of Pope Francis spark anew an important discussion: Are we alone in the Universe? The article follows traces of the idea of extraterrestrial life throughout philosophy, evaluates the current considerations about the probability of extraterrestrial life and discusses the potential implications for the discovery of such life from a theological point of view. This "thought experiment" covers basic insights on creation, revelation and redemption.

God "gave autonomy to the beings of the universe at the same time in which He assured them of his continual presence, giving life to every reality. And thus Creation has been progressing for centuries and centuries, millennia and millennia, until becoming as we know it today, precisely because God is not a demiurge or a magician, but the Creator who gives life to all beings. ${ }^{11}$

These words have recently been spoken by Pope Francis in the same address where he reiterated the affirmative catholic views on the Big Bang and on evolution, which created much media attention. They open up a surprising perspective on the likeliness of the discovery of extraterrestrial life. It seems so certain that there might be life beyond our planet to be discovered, that even the pope, speaking of "beings of the universe" instead only mentioning human beings, refers to this possibility. Why is this currently the case? And what is the history of this thought? In this article, we will follow traces of this idea throughout philosophy, evaluate the current considerations about the probability of extraterrestrial life and discuss the potential implications for the discovery of such life from a theological point of view.

\section{Introduction}

"The eternal silence of these infinite spaces fills me with dread." Pascal

Are we alone in the universe? Already in antiquity, there was an intensive debate on this question. The atomists, who perceived an infinite number of atoms as basic material of everything, allowed for a plurality of worlds, while the Aristotelians held the opinion that we live in a closed cosmos with earth in its center ${ }^{3}$. In the medieval age, it was the Aristotelian world view that dominated philosophy and theology, until the Copernican revolution paved the way for the assumption that not the sun is the center of the known world, but that there may be many solar systems like ours existing. And "a universe full of inhabited solar systems was applauded as one far more worthy of the infinite Creator than any of the other narrower schemes." ${ }^{4}$

In the wake of the Copernican Revolution, two widely assumed principles supported the idea that life is abundant in the universe, the Principle of Plentitude and that of Mediocracy. The former holds that 
a universe made by a perfect creator ought to be as rich as possible, and which universe could be richer than one that gives home to a plenitude life? The latter suggests that every place in the universe, in its basic properties, is similar to Earth - which is a principle still hold by modern science; yet it remains an open question whether or not it also applies to the existence of life, which could be a particular case on earth. ${ }^{5}$

The ambivalence of the idea that the human being, the "thinking reed" ${ }^{6}$, might find itself being lost in the infinity of an unenlivened space is well expressed by the $17^{\text {th }}$ century philosopher Blaise Pascal. Such a space would no longer allow for feeling at home in a meaningful, understandable cosmos: "No idea comes near it; it is no good inflating our conceptions beyond imaginable space, we only bring forth atoms compared to the reality of things. Nature is an infinite sphere whose centre is everywhere and circumference nowhere". Pascal, however, is still able to interpret this situation as referring to the greatness of God: "In short it is the greatest perceptible mark of God's omnipotence that our imagination should lose itself in that thought."

For only two hundred years, since man has understood that the Milky Way and the nebulae are galaxies, we know that myriads of stars exist out there. After decades where one did not expect many planets to exist at all ${ }^{8}$, it is in these very years that we start to discover planets ${ }^{9}$, too. But we haven't discovered any indication of life in the universe for now. Nor have we found a planet like Earth yet ${ }^{10}$. The more remarkable it is that a mission like Kepler has been started. "The mission is designed specifically to discover hundreds of earthsize and smaller planets in or near the habitable zone and determine the fraction of hundreds of billions of stars in our Galaxy that might have such planets." ${ }^{\prime 11}$ The name patron of the mission (and of the well-known physical laws), Johannes Kepler, a devout Christian ${ }^{12}$ of the $17^{\text {th }}$ century, was enthusiastic about the possibility of extraterrestrial life and actually expected Jupiter to be inhabited ${ }^{13}$.

\section{The Possibility of Contact}

The search for "habitable" planets and possible traces of extraterrestrial life is going on. What are the prospects of success? Not a few people can't imagine earth to be the only planet teeming with life. Novels and movies are full of science fiction, the imagination of contact with Extraterrestrial Life Forms, be them benevolent or malicious, intelligent, superior to humanity or only of a less complex kind. Yet even serious science feels obliged to attempt to communicate into space. Golden records onboard the voyager space probes symbolize the effort and hope for contact ${ }^{14}$, and already the first humanly constructed object to leave the solar system, Pioneer 10, carried basic data about human beings, too ${ }^{15}$.

Especially the SETI program has shown the fascination for listening to space - or better, the fascination for the idea that there might be some message to hear at all. Frank Drake, involved in this project, tried to calculate the number of detectable intelligent civilizations in our galaxy, using a rather simple equation, which is $N=R^{*} f_{p} n_{e} f_{i} f_{i} f_{c} L$. The variables are actually shortcuts for definitions: $N$ is the number of civilizations in our galaxy, whose electromagnetic emissions are detectable. 
$R^{*}$ is the rate of formation of stars per year suitable for the development of intelligent life.

$f_{P}$ is the fractions of those stars with planetary systems.

$n_{e}$ is the number of planets, per solar system, with an environment suitable for life.

$f_{i}$ is the fraction of suitable planets on which life actually appears.

$f_{i}$ is the fraction of life bearing planets on which intelligent life emerges.

$f_{c}$ is the fraction of civilizations that develop a technology that releases detectable signs of their existence into space.

$L$ is the length of time such civilizations release detectable signals into space.

This Drake equation is of course only a thinking device, not an exact physical equation. It identifies the specific factors that are relevant for discovering extraterrestrial intelligence (ETI). By multiplying them, one would obtain the number of civilizations in our galaxy, whose electromagnetic emissions are detectable.

What is the outcome of this equation? The problem is, that only the first three of its variables $\left(R^{*}, f_{p}\right.$ and $\left.n_{e}\right)^{16}$ can be established observationally, while its other factors are beyond current observations, as for now, we only have one case for them, that is Earth. Drake himself simply assumed the product of the first six factors $\left(R^{*} f_{p} n_{e} f_{l} f_{i} f_{c}\right.$. ) being 1 , reducing the equation to an approximation of the number of civilizations to the length of time such civilizations release detectable signals into space $(N \approx L)$, which he estimated to be 1,000-100 million years. He expected therefore an equal number of civilizations (1,000-100 million) in the Galaxy. Some were even more optimistic, others much less ${ }^{17}$.

But even if one day we would receive signals of another intelligent species, the problem would remain how to get in contact over such vast distances ${ }^{18}$. So maybe we are not alone, but nevertheless will never communicate with our neighbors? It could well be that extraterrestrial life exists in parts of the vastness of the universe which are beyond the possibility of contact or even of mere observation.

This conclusion is also suggested by the so-called Fermi paradox. After a meeting at Los Amalos, during lunch break, potential ET life was discussed ${ }^{19}$. Fermi suddenly speculated aloud 'where is everybody?', meaning: if there is no compelling evidence that any aliens have visited the Earth, then we must conclude that we are alone in the Galaxy. David Wilkinson explains Fermi's argument as follows: "[l]f Earth is not special in having intelligent life, then civilizations should already have evolved many times in the Galaxy, since there are billions of stars older than the Sun. If any of these civilizations wanted to colonize the Galaxy, they could have done so by now, even using technology that is almost within humanity's grasp." ${ }^{20}$ At least the latter claim is, however, highly disputable. Already the idea of traveling trough space is still much more a science-fiction-fantasy than a technology "almost within humanity's grasp", not to speak of the vast distances between the solar systems of a galaxy. What Fermi's reasoning does indicate, though, is that if there were intelligent life somewhere in the universe, it would presumably exist beyond the reach of our observation (not to speak of contact) - since otherwise, the absence of evidence for highly developed life in the observed space would surely be in need of explanation.

\section{Implications for finding ET Life}


So even if we might once be able to discover extraterrestrial life it will most likely be of more basic kind. Also the authors of the book Rare Earth argue "why complex life is uncommon in the Universe"21. They question the validity of the Principle of Mediocracy regarding life, rather employing a kind of Anthropic Principle, which expresses awe and wonder for the fact how unlikely it is that every factor regarding earth is just right to allow for the development of complex life on this planet ${ }^{22}$. Biologists tend to be equally more critical about the probability of complex life ${ }^{23}$, so it's probably really a rare earth. However, the authors of that book also concur with the assumption that basic life maybe widespread in the universe, as "life is tougher than we thought" ${ }^{24}$.

But even the discovery of some simple sort of ET life would mean something. We believe it to be well described by the title of a (German) book published by the Center for Space and Habitability of Bern University: “Archeology in Space" ${ }^{25}$. Discovery of unintelligent extraterrestrial life would help the discussion of questions of our origins, of the history of life.

Could space present the right place to look at? We have clues that this actually might be the case. The "Murchison" meteorite that landed in Australia 1969 contained several organic molecules, including amino acids ${ }^{26}$. "As this asteroid has been orbiting the inner Solar System since its birth, it indicated that the basic organic building blocks of life existed not only on the surface of the Earth but also in the inner Solar System. ${ }^{\prime 27}$ Could Earth then have received life from meteoritic and cometary impacts? Another potential birthplace for life are the molecular clouds of hydrogen in the space between the stars, which contain a rich variety of organic molecules. These molecules could seed the surfaces of newly formed planets with the next generation of stars. Indeed the surface of Earth has been heavily bombarded by asteroids and comets in earlier times. Additionally, the "furnace-like temperatures of entry into the atmosphere and impact itself could have caused gases to combine to form organic molecules." ${ }^{28}$ Some ${ }^{29}$ even assume the so-called 'panspermia' hypothesis that life might have developed in its most basic forms in space, and then transported by comets or when the Solar system passed through a gas cloud onto the surface of planets where it began to evolve ${ }^{30}$.

Be that as it may, if we do find life anywhere in space, it will probably greatly help biology. And as one could analyze how convergent this life has developed compared with life on Earth ${ }^{31}$, the outcome may lead to conclusions regarding the possibility of more developed ET life elsewhere in the universe, and how it may look like. However, Antonio Lazcano, biologist and former chairman of the International Society for the Study of the Origin of Life, still remains sceptic: "The search for life beyond Earth is a legitimate scientific question and an alluring intellectual endeavor that can best be served by keeping healthy distance from science-fiction scenarios and from the theological musings that somewhat surprisingly find their way into astrobiological meetings. Depending on who you speak to, astrobiology seems to include everything from the chemical composition of the interstellar medium to the origin and evolution of intelligence, society and technology - as if the Universe is following an inevitable upward linear path leading from the Big Bang to the appearance of life and civilizations capable of communication." ${ }^{32}$

While the "theological musings" in Lazcano's statement have the sound of "unreasonable metaphysical speculations", professional theologians concur with Lazcano in his critique. Ted Peters, for instance, stresses that in the field of astrobiology, "what we consider scientific knowledge is frequently mixed up with myth." ${ }^{33}$ He employs the term ETI myth "to refer to the belief that extraterrestrial intelligent beings exist and, further, they are more advanced than earthlings in 
evolution and technological progress .... Sometimes the myth includes still more; it includes trust in the evolutionary advance of intelligence and science, suggesting that more highly evolved ETIL [ExtraTerrestrial Intelligent Life] could bring scientific salvation to planet earth." ${ }^{34}$

As we will see, there is indeed a religious undertone to much of the SETI supporter's statements. Yet before we consider this, let us reflect on what the discovery of extraterrestrial life would mean for theology, for the belief in God. James Heiser, a Lutheran bishop and founding member of the Mars society, reflects on the implications of the discovery of life on Mars. If this life would stem from earth, for him this would have zero theological implications, but a second genesis on Mars "would signal the victory of the 'greater glory' position"35. This is the position we have referred to in the introduction, employing the principle of plenitude at its best.

Keeping the expectations low, there is still a promise to make, says astrophysicist Kevin Hand: "If funding permits, within the next few decades we will know the answer to whether or not life exists elsewhere in our Solar system." ${ }^{36}$ Yet, what if we do not find anything? Not even beyond our solar system? - We will still never know if we are alone in the universe, because as long as we do not find anything, we will always stay in the same situation as we are now ${ }^{37}$.

\section{A thought experiment: What if we detect ET life and it is intelligent indeed?}

Thus, we are certainly not in the situation that we have to face a soon discovery of ETI life as a possible event of any considerable probability. Nevertheless, in what follows, we want to reflect on the possibility of ETI life from a theological perspective since it is certainly this aspect that seems to challenge traditional Christian teaching most. The philosopher Hans Blumenberg once claimed that the "realisation of the hope for interstellar communication would necessarily result in the death of Christianity as well as of any religion"; at least, as he remarks more cautiously, theology has already to face "the subjunctive of the question [...] what it would mean if one day exobiology would get reason to develop into exoanthropology". ${ }^{38}$

Father T.J. Zubek is among those theologians who are quite optimistic with regard to this theological endeavour; he writes in the 1960s: "If we can understand that our way of encountering the universe and our views of spirituality only begin to express the range of ways that intelligent beings deal with Ultimate Reality; we are guaranteed to gain something very powerful: a more humble, more realistic, and yet paradoxically more complete and more extensive understanding of our own place in the universe." ${ }^{39}$ And David Wilkinson adds: Zubek's "challenge may hold true if we never actually make contact with life beyond Earth, but 'encounter' other forms of life only in hypothetical scenarios of our own construction." 40 So consider the following as a kind of thought experiment.

The three essential dimensions of the Christian understanding of human being, world and God relate to the creation, revelation and redemption/salvation. They all can be seen in some way or other as a specific interpretation of the ambivalence of human experience: We find ourselves in a world which 
resonances with our needs and desires as well as it conflicts with them; we encounter solidarity and love as well as conflict and hate; we participate in the beauty of the flourishing of life as well as in the harsh reality of dead. The Christian (and Jewish) narrative associates this ambivalent situation with God's creation, which is called "very good" by himself, on the one hand (Genesis 1:31), and an elementary, all-encompassing alienation from the originally intact relation between God, man and creatures on the other. In this story, revelation is the self-disclosure of God and His will to His creature that otherwise would not be able to know and hear Him anymore. And God's will aims at redemption or salvation, the perfection of the world as "very good", that is, as in the beginning God intended it. Christians see the drama of revelation and redemption centered and fulfilled in the figure of Jesus Christ.

Space does not allow us to discuss all aspects of this complex narrative. What we will do, however, is look at each area in turn how it might be seen from the 'perspective' that it constitutes and how it might be questioned or enriched by the possibility of ETI.

\subsection{Creation}

"In the beginning God created the heavens and the earth." Genesis 1,1

The Biblical creation narrative not only states that everything that is depends on God's creative action, but also, that human beings, man and woman alike, are created in the image of God. When we look at the original Hebrew text of the Bible closely, however, we might discover that we need not necessarily read this narrative as excluding the existence of extraterrestrial beings. God created heavens and the Earth, it is said; the Bible literally states: 'the heavens and the land', where land means the habitable world. God is the originator of the inhabitable cosmos as well as of the habitable, and the latter need not be confined to our planet. Furthermore, extraterrestrial beings could reflect God's image as well. Not only 'the first man', but any man is called 'adam', because he is taken from 'adamah', which means soil. So man is actually a 'soiling' or 'dustling' ${ }^{41}$ with a God-given breath and life, as the second creation narrative tells us. There may well be other 'dustlings' on other planets which are equally created in the image and inspired by the breath of God. Being created in the image of God means being a responsible steward for the habitable world ${ }^{42}$.

By the way, as it is often emphasized that human beings are nothing but animated stardust, this claim can well be integrated in the interpretative pattern suggested by the biblical narrative. This pattern seems to imply, however, that life - which is seen as a special gift of God - would exceed 'mere dust' and could not simply be reduced to it. It is of course obvious, that one would still need to discuss what life is in a creation (not: creationist) perspective that transcends a pure biological approach.

\subsection{Revelation}


More challenging than the concept of creation (which was attached to subject matters of so called "general revelation" by many Christian doctrinal traditions) seems to be the idea that God reveals himself through certain events in human history (which was often related to subject matters of "special revelation"). At first glance, it may appear that, in face of the possibility of ETI life, the relevance of this "special revelation" would be deeply questioned. Why should a complex corpus of narrative, moral, legal, hymnic, prophetic and wisdom traditions relating to the destiny of a small people in a remote area of the earth during a tiny piece of time have any concern to cosmic matters? Interestingly, Jewish and Christian religious traditions have always been quite conscious of the particularity of those events and memories through which they belief actually to know of God among them apparentness of God's name to Moses, the Exodus from Egypt, the giving of the Tora, and for Christians certainly the life, death and resurrection of Jesus Christ -; they have nevertheless maintained that it is no other than the universal God who chooses to disclose himself exactly in that particularity. The biblical key scene of the revelation of God's name to Mose in the epiphany of the burning bush might give some clue to this multifaceted relation between universality and particularity:

"I will be there howsoever I will be there." Exodus 3,14

God's proper name in the Hebrew Bible (YHWH, usually transliterated in Bible translations as "the LORD") showing God's very being is twofold, at least according to Martin Buber and Franz Rosenzweig who examined its meaning carefully in their translation of the Hebrew Bible into German. As such they interpret the biblical iteration with which the name is described (hebr. eheye asher ehyeh) as "I will be there howsoever I will be there." This means basically two things: Firstly, God is there, present in the history of human beings, and takes care, as promised by his name ${ }^{43}$. Second, man cannot predict in which shape God will show himself. He is free to choose his own mode of presence. Buber interprets this as a key to the plurality of religions ${ }^{44}$, and it could well apply to God showing himself in again other forms to other species as well. So, within the specific story constituting the perspectives inhabited by Jews and Christians respectively ${ }^{45}$, there is a key to understand that God is not restrained to the receptors of this "special revelation".

Such is also the situation with regard to biblical ethics. The Ten Commandments are ethical guidelines which summarize insights essential to the living together not only at the time of their reception but in many aspects until today. They are of course rooted in the history of the people of Israel. However, we want to argue, that they have a universal touch to them. The bible uses what the Rabbis called a klal be-torah ${ }^{46}$, summary of the law. Some parts are simply more important than others and summarize the teachings. The Ten Commandments themselves are already such a summarization of many detailed laws, but even they have been summarized further. The summary also expresses the spirit in which the commandment should be executed. This tradition has been reiterated by Jesus of Nazareth, when he was asked what the greatest commandment would be. He answered with the double commandment of love: "You shall love the LORD your God with all your heart, with all your soul, and with all your mind. This is the first and great commandment. And the second is like it: 'You shall love your neighbor as yourself.' On these two commandments hang all the Law and the Prophets." (Matthew 22:37-40 NKJV). By this, he simply followed the Jewish tradition, which summarized the first tablet of the Ten Commandments with the commandment to love God and the second tablet with the commandment to love your neighbor (Leviticus 19:18). 
"Your neighbor" was never restricted to one's own kind, but actually hinted toward the stranger in one's midst, to take care of him ${ }^{47}$. A very short version of this commandment is the golden rule, known in almost any religion ${ }^{48}$ : "Whatever you want men to do to you, do also to them, for this is the law and the prophets." (Matthew 7:12 NKJV) We do not believe it to be very difficult to apply this not only to men, but to any intelligent species as well, although this possibility is of course not within the original scope of the saying.

We could see, that also the ethical guidelines rooted in the biblical tradition point to their more general validity, in fact one can see this as well expressed in a quote from Paul:

"For since the creation of the world His invisible attributes are clearly seen, being understood by the things that are made, even His eternal power and Godhead" Romans 1,20 NKJV ${ }^{49}$

Science has actually grown out of the view of nature as another "Holy Book". The belief that nature carries information about God as well was actually an important motivation for the development of science $^{50}$. When the world is not God, but God's creation, it is not sacred but worth to be examined. And when it is God's voluntary creation, it makes sense to experiment with the world to understand how the God-given laws of nature work, as one could not deduce it purely from thinking, because his will transcends our thinking. This was the decisive advancement of modern science over ancient Greek philosophy of nature ${ }^{51}$.

We assume the tradition of reading in the 'book of nature' an important tradition which should be reconsidered. Much in this paper relies on the importance of a potential discovery in this 'book': the opening of a new chapter of Human history when contact with ETI might happen. The tradition of the book of nature as worth of intensive study may also help us to transcend too anthropocentric research approaches which solely focus on the discovery of habitable planets. Although this of course presents a highly important task, more general fundamental space research has its theological justification as well - for the glory of God, to understand a little bit "of his thoughts"

\subsection{Redemption: Incarnation \& Salvation}

We had omitted for now the centrality of the life of Jesus the Christ, which is no doubt constitutive for the Christian perspective. It is to these events to which we now turn, as they are closely connected with the doctrines of incarnation and salvation, which might provide the greatest challenge.

Already the $15^{\text {th }}$ century Franciscan Guillame de Vaurouillon ${ }^{53}$ probably was the "first author who raised the question whether the idea of a plurality of worlds is compatible with the central Christian notions of a divine incarnation and redemption".$^{54}$ The related questions are very old hence. However, this is not the place to review the various historical positions held in regard to the issue. We can only briefly consider the essential issues.

Christian creed confesses God to have become man in the person of Christ. If we assume ETI, it may be asked whether this expresses a preference of mankind over other galactic species, or if the incarnation in some way took place with other species, too. It could also be thought and has also 
been done so, that the uniqueness of man is expressed by his sin, viz. that other species have not sinned and do not need any redemptory action on behalf of God.

However let us assume that "all have sinned and fall short of the glory of God" (Romans 3:23), including potential extraterrestrial fellows ${ }^{55}$. If there is ETI, are there many incarnations needed then? Some have argued that this would force Christ to some planet hopping which makes the whole event quite incredible ${ }^{56}$. However, one can also find a more developed argument, like that of Cambridge physicist and priest John Polkinghorne.

He holds on to an old Christian creed ${ }^{57}$ which asserts that in Christ we see 'the taking of manhood into $\mathrm{God}^{\prime 58}$, and deduces from it that this 'taking' would have to partake of embodiment as essential to humanity. So the risen Christ is forever an embodied Christ. Now, "if there are other forms of self-conscious life in the universe, equally in need of redemption as humankind has proved to be" he would suppose "that the Second Person of the Trinity would, in his temporal pole, have taken upon himself their nature, and drawn that nature into Godhead in an act of redemption, thus finding a partial embodiment in them also." ${ }^{59}$

To understand this remark one must know of the Trinitarian structure of God in Christian belief, which evolved out of the problem to call Jesus Christ "LORD", a title usually reserved to the one God, and the wrestling with the idea of the Holy Spirit. So if there are not two or three Divine entities, the one God must show a differentiation within himself into three persons, the father, the son, and the Holy Spirit. Polkinghorne's approach now adds to the traditional Trinitarian structure temporal and eternal poles of the Godhead. Each person of the Trinity contains both poles, an idea Polkinghorne picked up from process philosophy. ${ }^{60}$ By this, he is taking serious the essential dimension of time. "While it is true that the God of becoming is needed if God is to be responsive to his evolving and suffering creation, it is also true that the God of being is needed if he is to be the guarantor of the order of creation and the ground of its hope. The modern scientific view of the universe, with its reliable underlying law but flexible open process, offers encouragement to the search for a dipolar God who is the source of the world's lawfulness and who interacts with its process." ${ }^{11}$

This move is actually most important to defend the thesis presented here that the challenge to understand the incarnation under the assumption of ETI can be met ${ }^{62}$. With Polkinghorne, we can conclude that "the more seriously one takes the divinity of Christ, the more seriously one must wrestle with the notion that the hypostatic union of his two natures" (viz., that Christ was fully man and fully God) "must involve something like the way in which an infinite-dimensional sphere would intersect a two-dimensional plane in the perfect symmetry of a circle. Then, if on other planets there are other created natures united to the Word, that would involve other 'sections' of the Divine sphere." ${ }^{\prime 63}$

If you should ask yourself now: why does theology develop such mind-boggling theories? Former particle physicist Polkinghorne would probably answer: "A scientist expects a fundamental theory to be tough, surprising and exciting." ${ }^{64}$

Polkinghorne further explores what he calls the 'scandal of particularity': While science works according to general laws of nature, theology is related to events which have a unique ring to them, like the revelatory events already mentioned, and the life, death and resurrection of Jesus Christ. We would maintain that the 'scandal of particularity' is even more scandalous than Polkinghorne holds. Jesus was a Jewish man of Galilee, and Christians believe him to be the promised Messiah (anointed one, Greek 'Christ', hence 'Christians' are those that believe Jesus to have been the 
Messiah), which in fact is inseparable not only from his being human, but also from his being a Jew. Thus, when we say that Jesus Christ is the center of Christian belief, we must not forget that we can neither understand the historical person Jesus nor the complex of ideas connected with "Christ» independent from a very specific historical, social and religious context. On the other hand, there is an explicit notion of Christ's cosmic importance in the biblical Texts of the New Testament and in the tradition of the Church. Christ "is the image of the invisible God, the firstborn over all creation. For by Him all things were created that are in heaven and that are on earth, visible and invisible, whether thrones or dominions or principalities or powers. All things were created through $\mathrm{Him}$ and for Him. And He is before all things, and in Him all things consist." (Colossians 1:15-17). Modern tradition has called this the Cosmic Christ ${ }^{65}$. Note that in these verses ${ }^{66}$ the possibility of other intelligences than human is actually included, pointing to the old tradition of the existence of angels in the invisible world.

One could assume, although interpretations in these regards may vary, that we have witnessed a historical development of one religion (Judaism) into an even more universal, new one (Christianity). This development was based on the universalistic strands within Judaism itself. If another development would be necessary, this could certainly lead to a new religion on Earth. However we believe Christianity to be developed enough to understand the incorporation of potential ETI into the "body of Christ" (1. Corinthians 12,12ff; Colossians 1:18). The figure of thought employed for this is that Christians believe Christ to be the Word of God, through which the whole creation is made (Genesis 1, John 1), as also expressed in the Cosmic Christ.

This passage of the cosmic Christ actually continues by also expressing Christ's "soteriological", that is reconciling dimension in the whole cosmos (Colossians 1:19-20). If we do not want this to interfere with the possibility of many incarnations, it can again be imagined to work in the way John Polkinghorne pointed out, therefore leaving room for other tempospatial incarnations. To put it bluntly, including a good portion of British Humor: "If little green men on Mars need saving, then God will take little green flesh" ${ }^{67}$

\section{Conclusion}

Two years after the French Revolution, and very much in the spirit of that age, Thomas Paine holds in his The Age of Reason that "to believe that God created a plurality of worlds, at least as numerous as what we call stars, renders the Christian system of faith at once little and ridiculous, and scatters it in the mind like feathers in the air." ${ }^{168}$ One should however not forget when this statement was made, and that it is dependent on a literal interpretation of the story of Adam and Eve, for instance.

Theology has developed since then, we would argue. The outcome of our thought experiment here is that far from presenting an essential thread to Christianity, the discovery of ET life as result of the study of the 'book of nature' would only advance the understanding of the infinite glory of God in his creation. If the life discovered would even be intelligent, this would provide a challenge to overcome too anthropocentric concepts within Christianity. We believe the challenge could be met, as Christianity provides the resources for it. Its revelatory tradition has a universalistic tendency that 
makes this possible. One would have to accept extraterrestrials as created in the image of God and created through the word of God, viz. Christ, as well. Whether many incarnations were needed or whether the one on Earth suffices for all species, we want finally to leave to the wisdom of God, but we like John Polkinghorne's answer to the question which combines particularity (the planes) with universality, viz. God's infinity (the sphere).

Therefore one would not need to send missionaries into space ${ }^{69}$. More, it would be much that we could learn about God from our ET fellow beings and their religious tradition. May the Jewish philosopher of religion Franz Rosenzweig have the last word in these regards. He emphasizes that despite the truth claims of the divergent religious traditions, including his own one, the whole truth remains with God. "Thus truth must be verified, and precisely in the manner in which it is generally denied, that is, by leaving aside the 'whole' truth and by yet recognizing the portion to which one holds as the eternal truth."10

\footnotetext{
${ }^{1}$ Address of his Holiness Pope Francis on the occasion of the Inauguration of the Bust in Honour of Pope Benedict XVI, Casina of Pius IV, Monday, 27 October 2014, http://w2.vatican.va/content/francesco/en/speeches/2014/october/documents/papa-francesco_20141027_pl enaria-accademia-scienze.html, retrieved on 5 November 2014. Italics by the authors of this paper.

2 Blaise Pascal, Pensées, ed. A. J. Krailsheimer, Rev. ed., Penguin classics (London, New York: Penguin Books, 1995), 66 (fragment no. 201/206).

${ }^{3}$ Nevertheless there were theologians who considered intelligent life on other celestial bodies on basis of their respective metaphysics, cf. Thomas F. O'Meara, O.P., "Christian Theology and extraterrestrial intelligent Life," Theological Studies, no. 60 (1999).

${ }^{4}$ Steven J. Dick, Life on other worlds: The 20th-century extraterrestrial life debate (Cambridge, New York: CUP, 1998), 14-15.

${ }^{5}$ Michael J. Crowe and Matthew F. Dowd, "The Extraterrestrial Life Debate from Antiquity to 1900," in Astrobiology, History, and Society: Life Beyond Earth and the Impact of Discovery, ed. Douglas A. Vakoch (Berlin: Springer, 2013), 4-56: 7.

${ }_{6}^{6}$ Pascal, Pensées, 66 (Fragment no. 200/347).

7 Pascal, Pensées, 60 (fragment no. 199/72). This fragment seems to refer to the Copernican model; but there is still some debate on that. See Michael J. Crowe and Matthew F. Dowd, "The Extraterrestrial Life Debate from Antiquity to 1900," in Astrobiology, History, and Society: Life Beyond Earth and the Impact of Discovery, ed. Douglas A. Vakoch (Berlin: Springer, 2013), 4-56, 52.

${ }^{8}$ Part time one did not assume many planets to exist, cf. David Wilkinson, Science, religion, and the search for extraterrestrial intelligence, First edition (Oxford: OUP, 2013), 27-8.

9 The first exoplanet circling a sunlike star was discovered in 1995.

${ }^{10}$ The recent announcement of the discovery of Kepler $186 f$, a roughly Earthsize planet in the habitable zone of its star Kepler 186, however doesn't do much to change the scenario, as it is probably far from being a second earth already.

${ }^{11}$ Wilkinson, Science, religion, and the search for extraterrestrial intelligence, 51 . This paper owes much to Wilkinson's comprehensive overview on the topic.

12 Jürgen Hübner, Die Theologie Johannes Keplers zwischen Orthodoxie und Naturwissenschaft, Beiträge zur historischen Theologie 50 (Tübingen: Mohr, 1975).

13 Michael J. Crowe and Matthew F. Dowd, "The Extraterrestrial Life Debate from Antiquity to 1900," in Astrobiology, History, and Society: Life Beyond Earth and the Impact of Discovery, ed. Douglas A. Vakoch (Berlin: Springer, 2013), 4-56, 11.

${ }^{14}$ Carl Sagan, Murmurs of earth: The Voyager interstellar record : a gallery of photographs reflecting our planet and ourselves, Commemorative ed (Burbank, CA: Warner New Media, 1992).

${ }^{15}$ Wilkinson, Science, religion, and the search for extraterrestrial intelligence, 92.

${ }^{16}$ Observations of the Kepler space telescope suggest that every tenth star has a planet, so $f_{p}$ would be the first variable to be determined (at 0,1). Cf. N. M. Batalha, "Exploring exoplanet populations with NASA's Kepler Mission", in: Proc. Natl. Acad. Sci. U.S.A. 111 (2014), 12647-12654.

17 Wilkinson, Science, religion, and the search for extraterrestrial intelligence, 40.
} 
18 Ibid., 41.

19 The accounts of the story differ regarding the topic. Eric M. Jones, "Where is everybody? An account of Fermi's question," Physics today 38.2, August (1985).

20 Wilkinson, Science, religion, and the search for extraterrestrial intelligence, 98 . There are many more potential 'solutions' to the Fermi paradox, presented in a comprehensive book by Stephen Webb, If the universe is teeming with aliens ... where is everybody? Fifty solutions to the Fermi paradox and the problem of extraterrestrial life (New York: Copernicus Books in association with Praxis Pub., 2002).

${ }^{21}$ Subtitle of Peter Douglas Ward and Donald Brownlee, Rare earth: Why complex life is uncommon in the universe (New York: Copernicus, 2000).

22 Ibid., xxxi-xxxii.

23 Wilkinson, Science, religion, and the search for extraterrestrial intelligence, 69.

24 Ward and Brownlee, Rare earth, 4.

25 Kathrin Altwegg, ed., Archäologie im All: Die Suche nach dem Ursprung des Lebens, 1st ed. (Bern: Haupt, 2009).

26 Keith Kvenvolden et al., "Evidence for Extraterrestrial Amino-acids and Hydrocarbons in the Murchison Meteorite," Nature 228, no. 5275 (1970), doi:10.1038/228923a0.

27 Wilkinson, Science, religion, and the search for extraterrestrial intelligence, 63.

28 Ibid., 64.

29 E.g. Fred Hoyle and Chandra Wickramasinghe, Evolution from space: $A$ theory of cosmic creationism, 1st Touchstone ed (New York: Simon and Schuster, 1984).

30 Wilkinson, Science, religion, and the search for extraterrestrial intelligence, 64.

31 S. Conway Morris, Life's solution: Inevitable humans in a lonely universe (Cambridge, UK, New York: CUP, 2003).

32 Antonio Lazcano and Kevin P. Hand, “Astrobiology: Frontier or fiction,” Nature 488, no. 7410 (2012): 160, doi:10.1038/488160a.

33 Ted Peters, "Astrotheology and the ETI Myth," Theology and Science 7, no. 1 (2009): 4, doi:10.1080/14746700802617097, http://dx.doi.org/10.1080/14746700802617097.

34 Ibid.

35 James D. Heiser, A shining city on a higher hill: Christianity and the next new world, 1st ed. (Malone, Tex: Repristination, 2006), 47.

36 Lazcano and Hand, “Astrobiology: Frontier or fiction," 161.

37 We seriously doubt that human beings will ever explore the whole cosmos.

38 Hans Blumenberg, Die Vollzähligkeit der Sterne, (Frankfurt am Main: Suhrkamp) 2000, $145 f$.

39 Quoted in Wilkinson, Science, religion, and the search for extraterrestrial intelligence, 129.

40 Ibid..

41 "For dust you are and to dust you shall return" (Genesis 3:19 NKJV).

42 Christian Link, Schöpfung, (Neukirchen-Vluyn: Neukirchener) 2012, 98-108.

43 It is certainly not by chance, that Jesus Christ was also called Immanuel, which means "God with us"

(Matthew 1:23). One can question this of course for devastating historical experiences. It is thought-provoking, that Martin Buber understood these experiences as results of not listening to God while he is still there. Martin Buber, "Gottesfinsternis," in Werke: Erster Band. Schriften zur Philosophie, ed. Martin Buber (München, Heidelberg: Kösel; L. Schneider, 1962), 503-603

44 Martin Buber, “Königtum Gottes," in Werke: Zweiter Band. Schriften zur Bibel, ed. Martin Buber (München, Heidelberg: Kösel; L. Schneider, 1964), 485-723, 624.

${ }^{45}$ We take these concepts from Dietrich Ritschl, The Logic of Theology. A Brief Account of the Relationship between Basic Concepts in Theology, Philadelphia 1987.

46 Babylonian Talmud 31a.

47 Hermann Cohen, Religion der Vernunft aus den Quellen des Judentums: Eine jüdische Religionsphilosophie, Neu gesetzte und überarbeitete Ausgabe (Wiesbaden: Marix, 2008), 171.

48 Jeffrey Wattles, The Golden Rule (New York: OUP, 1996), 4.who also discusses the limitations of the rule.

49 The meaning of the biblical quote above actually has been a matter of quite some dispute between Christian denominations and within Protestant thought, too. Does it mean that one can actually get material knowledge 
of God by reasoning alone on his works, viz. creation? Or does it only mean, that there is some basic intuition about God we can acquire so there is no excuse not to look further?

50 Peter Harrison, The Bible, Protestantism, and the rise of natural science, 1. Publ. (Cambridge et. al.: CUP, 1998).

51 In protestant thought, this achievement has been downplayed in the last century, due to the outcome such

a 'natural theology' had in Nazi Germany (the historical events around Hitler's coming-to-rule were interpreted by many German Christians as divinely inspired). It is therefore clear, that natural theology can't be a source of the preaching of the church, because man can be just so wrong in deducing its insights.

52 Cf. Hübner, Die Theologie Johannes Keplers zwischen Orthodoxie und Naturwissenschaft, 170; Max Jammer, Einstein and religion: Physics and theology (Princeton, NJ: PUP, 1999), 123.

53 Engl. spelling "William Vorilong".

54 Michael J. Crowe, "A History of the Extraterrestrial Life Debate," Zygon 32, no. 2 (1997): 149, doi:10.1111/0591-2385.801997079.

55 This might provoke a debate regarding the very nature of sin of course.

${ }^{56}$ Such is the argument of Thomas Paine in his Age of Reason, see Michael J. Crowe and Matthew F. Dowd, "The Extraterrestrial Life Debate from Antiquity to 1900," in Astrobiology, History, and Society: Life Beyond Earth and the Impact of Discovery, ed. Douglas A. Vakoch (Berlin: Springer, 2013), 4-56, 24.

57 The Athanasian Creed in this case, a creed in use in all of the Western churches, especially in the Anglican Communion. Athanasius' name seems to have become attached to it as a sign of its strong dedication to Trinitarian faith.

58 J. C. Polkinghorne, Science and providence (London: SPCK, 1989), 90.

59 Ibid., 91.

60 Ibid., ch. 7.

61 Ibid., 80.

62 For a critical review of Christian doctrine under the ETI assumption, see Christian Weidemann, "Christian Soteriology and the ETI-Hypothesis," Journal of the British Interplanetary Society (forthcoming). For his critical evaluation, he makes use of the principle of mediocrity, Romans 6:9 and the Creed of Chalcedon.

${ }^{63}$ Polkinghorne, Science and providence, 91.

64 J. C. Polkinghorne, Science and Christian belief: Theological reflections of a bottom-up thinker : the Gifford Lectures for 1993-4 (London: SPCK, 1994), 1.

${ }^{65}$ Cf. Werner Thiede, Wer ist der kosmische Christus? Karriere und Bedeutungswandel einer modernen Metapher, Kirche, Konfession, Religion Bd. 44 (Göttingen: Vandenhoeck \& Ruprecht, 2001).

${ }^{66}$ Along with the Nicene Creed by the way.

${ }^{67}$ Polkinghorne, quoted in Wilkinson, Science, religion, and the search for extraterrestrial intelligence, 169.

68 Thomas Paine, The Age of Reason: Being an Investigation of True and Fabulous Theology (Paris: Barrois, 1794), 84.

${ }^{69}$ If mankind by chance would present the most developed species when contact with ETI happens, one could probably learn from history of the coming-to the 'new world' how to deal with it in a more appropriate fashion. Our thanks go to Luca di Blasi and Antonio Lazcano for pointing this out.

${ }^{70}$ Franz Rosenzweig, The Star of Redemption (Notre Dame, IN: NDP, 1985), 393. 